\title{
RESEARCH UPDATE
}

\section{The Origins of Stonehenge: On the Track of the bluestones}

\author{
Mike Parker Pearson*, Josh Pollard ${ }^{\dagger}$, Colin Richards ${ }^{\ddagger}$ and \\ Kate Welham ${ }^{\S}$
}

Stonehenge is unique among prehistoric stone circles. Its stones are shaped and they carry lintels but the most extraordinary feature is that its stones have been brought to Salisbury Plain from elsewhere. Stonehenge's sarsen stones (a type of silcrete) are thought to have been brought from the Marlborough Downs 20 miles $(30 \mathrm{~km}$ ) to the north (Parker Pearson 2016). More extraordinarily, the smaller 'bluestones' (mostly under $4 \mathrm{~m}$ long and under 4 tons each) come from the Preseli region of west Wales, 140 miles $(225 \mathrm{~km})$ away. 'Bluestone' is actually a term that covers Stonehenge stones of varying geology: spotted dolerite, ordinary dolerite, rhyolite, volcanics and sandstone.

Stonehenge was built in five stages, the earliest dating to 3000-2755 BC and the second stage (when the sarsen circle and trilithons - two upright stones with a third across the top - were erected) to 2620-2480 BC (Darvill et al. 2012). Twentieth-century archaeologists used to think that the bluestones

\footnotetext{
* UCL Institute of Archaeology, London WC1H OPY, UK

+ University of Southampton, Department of Archaeology, UK

₹ University of the Highlands and Islands, Department of Archaeology, UK

§ University of Bournemouth, Department of Anthropology, Archaeology and Forensic Science, UK

Corresponding author: Mike Parker Pearson (m.parker-pearson@ucl.ac.uk)
}

did not arrive at Stonehenge until long after this first stage (Atkinson 1979; Cleal, Walker and Montague 1995) but reassessment of early $20^{\text {th }}$-century excavations, coupled with re-excavation inside Stonehenge, has raised the probability that the bluestones were installed in its first stage (Parker Pearson et al. 2009; Willis et al. 2016). We now think that bluestones were set into pits known as the Aubrey Holes to form a circle of standing stones at this early date. A second, smaller bluestone circle ('Bluestonehenge') was erected nearby, beside the River Avon at West Amesbury (Allen et al. 2016).

\section{Geological Sources for Stonehenge's Bluestones}

Geologists have recently identified several of the sources of bluestones through geochemistry and petrography (Ixer and Turner 2006; Ixer et al. 2017). The major source of the spotted dolerite is a small outcrop called Carn Goedog on the north flank of the Preseli hills (Bevins, Ixer and Pearce 2013). Just west of Carn Goedog is Cerrigmarchogion, now identified as the likely source of Stonehenge's unspotted dolerite. Two miles ( $3 \mathrm{~km}$ ) to the north of Carn Goedog is Craig Rhos-y-felin, an outcrop of rhyolite recently identified as the source of one or more of Stonehenge's rhyolite bluestones (Ixer and Bevins 2011).

Archaeological excavations were carried out at Craig Rhos-y-felin in 2011-2015 and at Carn Goedog in 2014-2016 to search for traces of Neolithic megalith-quarrying and 
to date these remains to confirm whether the bluestones could have been installed at Stonehenge in its first stage. At Craig Rhos-yfelin and Carn Goedog the rock forms natural pillars separated by vertical jointing which makes these pillars relatively easy to detach. The Neolithic megalith-quarry workers would have had to free each pillar, then lower it onto a wooden sledge and drag it away. They probably did not shape these monoliths at the quarries. Most of Stonehenge's bluestones, in contrast to the sarsens, have not been shaped (dressed); those that have, display the same style of transverse dressing as applied to the sarsen trilithons (Abbott and Anderson-Whymark 2012). Since these trilithons were not erected at Stonehenge until Stage 2, it seems likely that dressing of the bluestones took place at Stonehenge some centuries after Stage 1.

\section{Craig Rhos-y-felin Megalith Quarry}

Geological identification of just where the Stonehenge rhyolite came from on the Craig Rhos-y-felin outcrop is extremely precise. Due to the unusual micro-structure of the rock, it was possible to provide a close match at just one specific location on the rock face. This is exactly at the spot where there is a recess from which a $0.4 \mathrm{~m}$-wide, $2.5 \mathrm{~m}$ long pillar is missing (Parker Pearson et al. 2015). After three seasons of excavation we reached the Neolithic deposits beside the outcrop, which consisted of a small hearth and associated spread of occupation debris within $2 \mathrm{~m}$ of the recess. Finds were sparse, consisting of a few tools and flakes of rhyolite and flint and the carbonised remains of wood and hazelnut shells. The latter provided two radiocarbon dates of 3620-3360 BC and 3500-3120 BC (Parker Pearson et al. 2015) (Fig. 1).

Yet this Neolithic horizon was just one of a series of human encounters with the outcrop of Craig Rhos-y-felin (Parker Pearson et al. 2015). Mesolithic hunter-gatherers had used the place as a camp site several times between 8000 BC and 5000 BC. Around 2000 BC, Bronze Age famers came here to quarry megaliths. They constructed a level platform of rock and soil, onto which they manoeuvred a 4-ton pillar but left it there possibly because a large flake had sheared off its underside. We can only assume that it had been intended for use as a Bronze Age standing stone, perhaps to be erected at the nearby burial cairn of Pensarn. Much of the area around the outcrop was covered in colluvium around 1000 BC, after which Iron Age people camped here. With this long span of human activity at Craig Rhos-y-felin, how could we be sure that the Neolithic occupation was associated with megalith-quarrying?

In 2014-2015 at Craig Rhos-y-felin we found the remains of a level, artificial platform earlier than the Bronze Age one. This was located $5 \mathrm{~m}$ from the pillar recess and, when constructed, had been held in place by a small drystone wall of which just two courses have remained. The platform was constructed of sediment and small stones interspersed with vertically set stone slabs and capped by two large, flat boulders, one of which had since slid downslope, breaking through the wall (Parker Pearson et al. 2015). This side of the platform had once stood $0.7 \mathrm{~m}$ above ground level, providing a suitable 'loading bay' from which a monolith could be lowered onto a sledge and hauled away. From the foot of the wall, a hollow trackway, $2 \mathrm{~m}$ wide, led away from the outcrop. We followed it for $10 \mathrm{~m}$ within our trench where it leads northwards alongside the small stream that flows past the outcrop.

The trackway had been created by trampling the soft alluvial silt of the valley bottom, presumably by dragging megaliths on wooden sledges away from the platform. This silt had been laid down in the Late Mesolithic around 5500 BC. The trackway was itself filled with alluvial sediment which was also the first layer to form against the drystone wall of the platform. Radiocarbon dates on charcoal from directly on top of the trackway reveal that it had been in use shortly before 3270-2910 BC, around the time of Neolithic occupation beside the monolith recess. Charcoal fragments incorporated into the sediments of the platform were much older, around $5000 \mathrm{BC}$ - the Late Mesolithic - but these are probably residual since one of the 


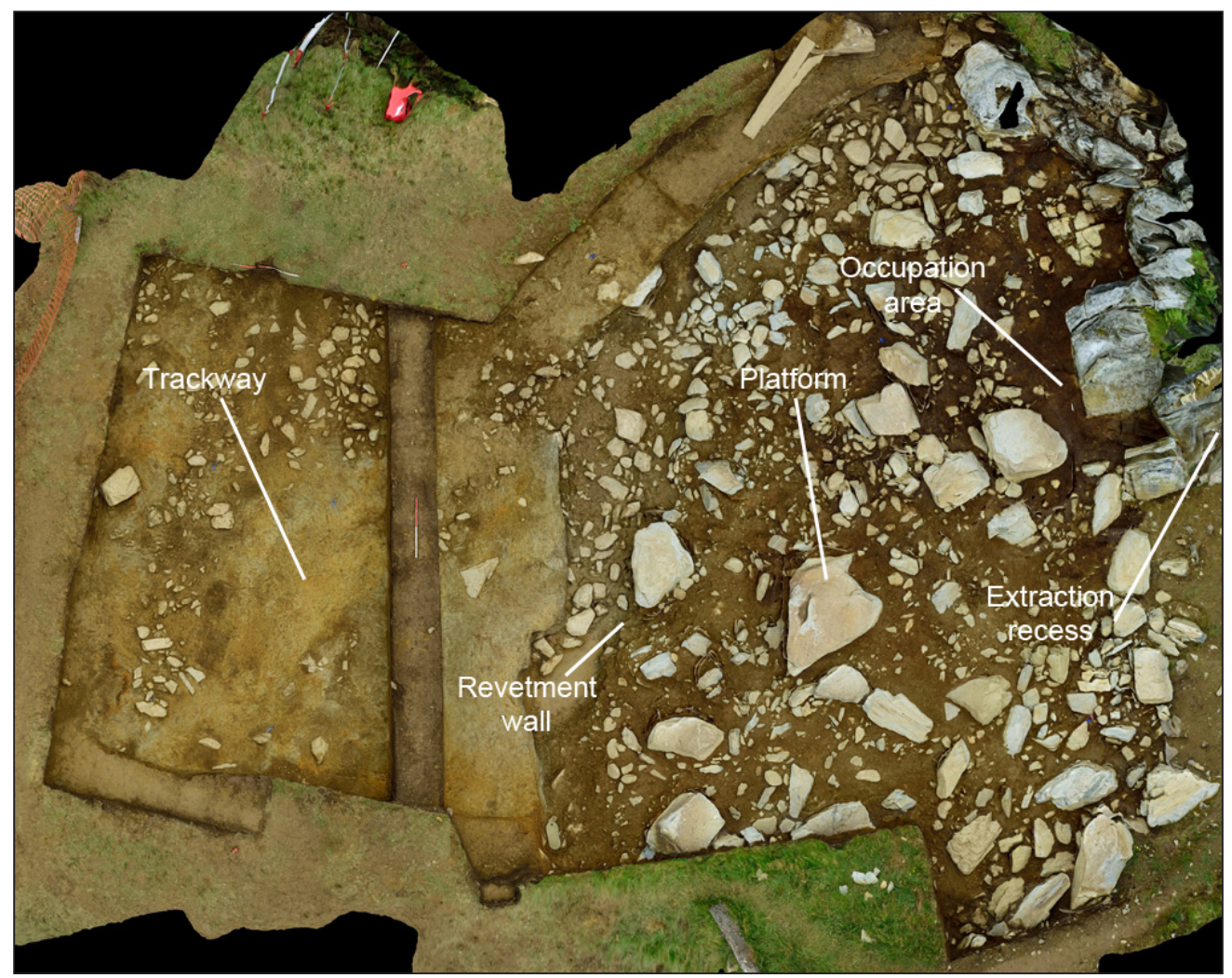

Figure 1: An aerial photogrammetric vertical view of excavations at Craig Rhos-y-felin showing the outcrop, the Neolithic platform and revetment wall, and the trackway; North is at the bottom left (Photo Adam Stanford).

finds from these platform sediments is a very fine end-scraper, a type of stone tool characteristic of the Neolithic.

In summary, the Craig Rhos-y-felin sequence has produced evidence for an artificial platform and trackway leading away from it, adjacent to the recess from which a pillar was removed, a pillar that eventually ended up at Stonehenge. Dating evidence from the trackway and platform, as well as from the occupation deposit beside the recess, reveals that this episode of megalith-quarrying took place most likely at some time in the period 3500-3360 BC.

\section{Carn Goedog Megalith Quarry}

At least five stones at Stonehenge are sourced to Carn Goedog (Bevins, Ixer and Pearce 2013). We found only one access point through the surrounding scree where suitable natural pillars could be quarried. Part of this accessible area has been affected by post-medieval quarrying but, just east of it, the outcrop retains evidence of more ancient removal of many whole pillars. At the foot of this rock face, excavations revealed an artificial platform of large slabs, many of them split in half with their split faces uppermost. Sediments from within and underneath the platform produced charcoal fragments which have yielded six dates in the Neolithic, most of which cluster around 3350-3020 BC. The latest of these dates to 3020-2880 BC. The platform was out of use when a small fire pit was cut into the top of it, with charcoal dating to 2890-2630 BC (Fig. 2).

The Carn Goedog platform, like the Neolithic platform at Craig Rhos-y-felin, terminates away from the outcrop in a vertical 0.9 m drop to form a loading bay where 
monoliths could be loaded onto sledges. However, there is no sign of a trackway in the hard ground leading away from it. Just beyond the edge of the platform we found an $11 \mathrm{~m}$-long, $3 \mathrm{~m}$-wide ditch. Dug to a depth of $0.4 \mathrm{~m}$, its upcast was deposited on the side away from the outcrop and the ditch was then filled with large stones, creating a permanent barrier across which no monolith could be transported. The latest radiocarbon date on charcoal from this ditch indicates that it was filled-in around or after 3020-2880 BC.

In summary, Carn Goedog's main period of monolith extraction was slightly later than at Craig Rhos-y-felin, in the two or three centuries before 3000 BC. The same method was used of lowering monoliths onto a level platform, in this case built largely of large flat slabs with sediment in between them, sitting on top of the Neolithic ground surface.
Unlike Craig Rhos-y-felin, no hollow way was formed by the hauling-away of monoliths, presumably because the hard ground and tough grass cover on this elevated hillside were not eroded by moving stones over the surface. The construction of a stone-filled ditch (the date of which coincides with Stage 1 at Stonehenge) as a barrier to cut off access to bluestone pillars from the outcrop, is intriguing. It may have served to prevent removal of any more of these important stones.

\section{An Original Stonehenge in Wales?}

So where were the bluestones of Craig Rhosy-felin and Carn Goedog initially taken? Since monoliths were extracted at different times from the two quarries, it seems likely that they were incorporated either into two monuments or into a two-phase monument, likely to be located in their vicinity, before

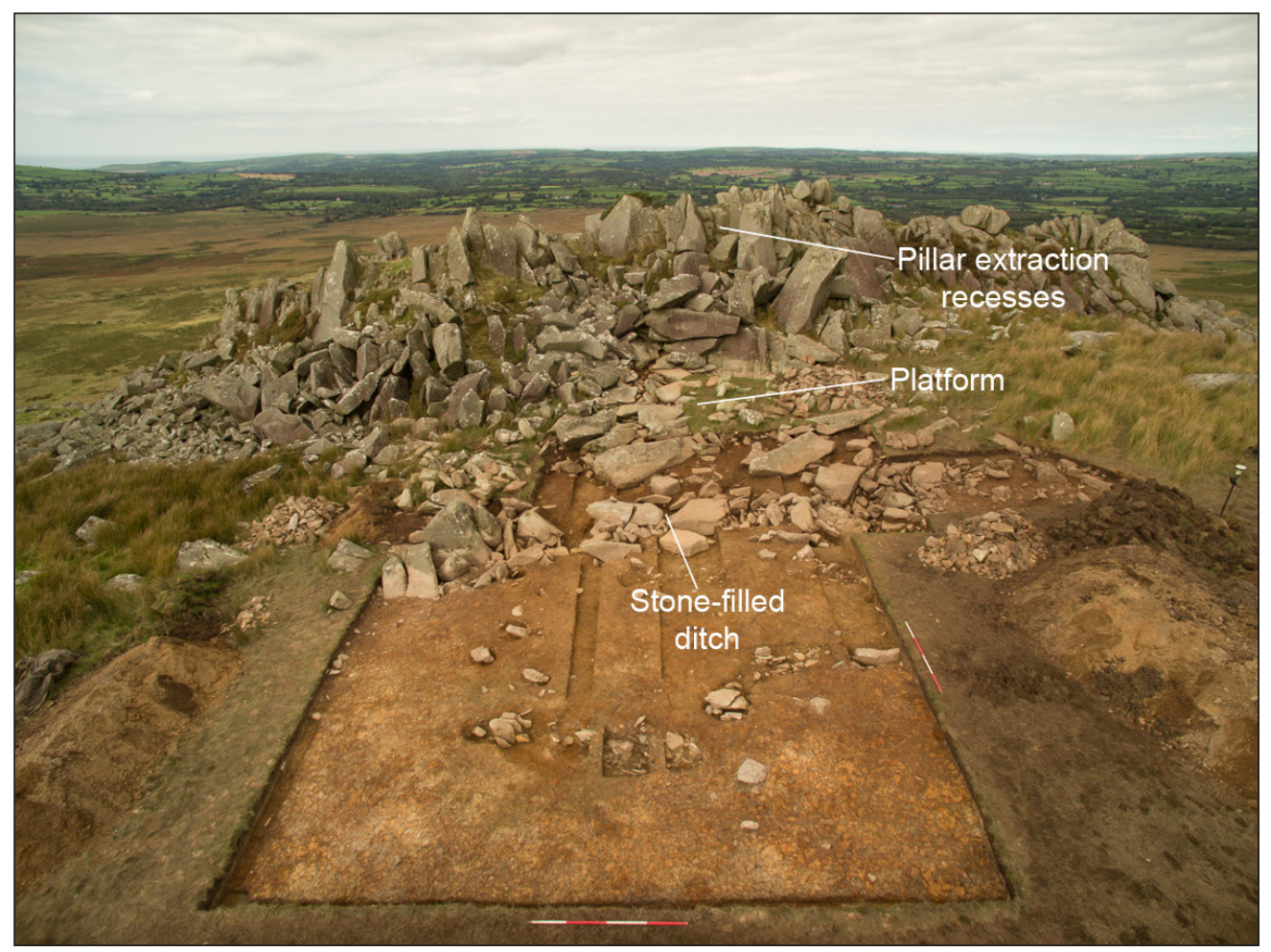

Figure 2: Excavations at Carn Goedog, viewed from the South, showing the outcrop, the Neolithic platform and the stone-filled Neolithic ditch (Photo Adam Stanford). 
being dismantled and taken to Salisbury Plain to be erected there in 3000-2755 BC. If this is so, then where and what might this original 'Stonehenge' be? Somewhere in the vicinity of these quarries may lie the remains of one or more stone circles that formed the original Stonehenge, just waiting to be found. One of the greatest archaeological discoveries in world archaeology may be just around the corner.

\section{Competing Interests}

The authors have no competing interests to declare.

\section{References}

Abbott, M, Anderson-Whymark, H, Aspden, D, Badcock, A, Davies, T, Felter, M, Ixer, R, Parker Pearson, $\mathbf{M}$ and Richards, C 2012 Stonehenge laser scan: archaeological analysis report. English Heritage Research Report 32/2012. Swindon: English Heritage.

Allen, M J, Cleal, R M J, French, C A I, Marshall, P, Pollard, J, Richards, C, Ruggles, C, Rylatt, J, Thomas, J, Welham, Kand Parker Pearson, M 2016 Stonehenge's avenue and Bluestonehenge. Antiquity, 30: 991-1008. DOI: https://doi.org/10.15184/aqy.2016.98

Atkinson, R J C 1979 Stonehenge. Third edition. Harmondsworth: Penguin.

Bevins, R E, Ixer, R A and Pearce, N G 2013 Carn Goedog is the likely major source of Stonehenge doleritic bluestones: evidence based on compatible element geochemistry and principal components analysis. Journal of Archaeological Science, 42: 179-93. DOI: https://doi.org/10.1016/ j.jas.2013.11.009

Cleal, R M J, Walker, K E and Montague, R 1995 Stonehenge in its Landscape: twentiethcentury excavations. London: English Heritage.

Darvill, T, Marshall, P, Parker Pearson, M and Wainwright, G J 2012 Stonehenge remodelled. Antiquity, 86: 1021-40. DOI: https://doi.org/10.1017/s0003598x000 48225

Ixer, R A and Bevins, R E 2011 Craig Rhos-yfelin, Pont Saeson is the dominant source of the Stonehenge rhyolitic 'debitage'. Archaeology in Wales, 50: 21-31.

Ixer, R A and Turner, P 2006 A detailed re-examination of the petrography of the Altar Stone and other non-sarsen sandstones from Stonehenge as a guide to their provenance. Wiltshire Archaeological and Natural History Magazine, 99: 1-9.

Ixer, R A, Turner, $\mathbf{P}$, Molyneux, $\mathbf{S}$ and Bevins, R E 2017 The petrography, geological age and distribution of the Lower Palaeozoic Sandstone debitage from the Stonehenge landscape. Wiltshire Archaeological and Natural History Magazine, 110: 1-16.

Parker Pearson, M 2016 The sarsen stones of Stonehenge. Proceedings of the Geologists' Association, 127: 363-9. DOI: https://doi.org/10.1016/j.pgeola.2015. 07.004

Parker Pearson, M, Bevins, R E, Ixer, R A, Pollard, J, Richards, C, Welham, K, Chan, B, Edinborough, K, Hamilton, D, Macphail, R, Schlee, D, Simmons, E and Smith, M 2015 Craig Rhos-y-felin: a Welsh bluestone megalith quarry for Stonehenge. Antiquity, 89: 1331-52. DOI: https://doi.org/10.15184/aqy.2015.177

Parker Pearson, M, Chamberlain, A, Jay, M, Marshall, P, Pollard, J, Richards, C, Thomas, J, Tilley, $\mathbf{C}$ and Welham, K 2009 Who was buried at Stonehenge? Antiquity, 83: 23-39. DOI: https://doi. org/10.1063/pt.5.029183

Willis, C, Marshall, P, McKinley, J I, Pitts, M, Pollard, J, Richards, C, Richards, J, Thomas, J, Waldron, T, Welham, K and Parker Pearson, M 2016 The dead of Stonehenge. Antiquity, 90: 337-56. DOI: https://doi.org/10.15184/aqy.2016.26 
How to cite this article: Parker Pearson, M, Pollard, J, Richards, C, and Welham, K 2017 The Origins of Stonehenge: On the Track of the bluestones. Archaeology International, No. 20: pp. 52-57, DOI: https://doi.org/10.5334/ai-353

Published: 14 December 2017

Copyright: (c) 2017 The Author(s). This is an open-access article distributed under the terms of the Creative Commons Attribution 4.0 International License (CC-BY 4.0), which permits unrestricted use, distribution, and reproduction in any medium, provided the original author and source are credited. See http://creativecommons.org/licenses/by/4.0/.

] $\mathrm{u}\left[\begin{array}{l}\text { Archaeology International is a peer-reviewed open access journal } \\ \text { published by Ubiquity Press. }\end{array}\right.$ 